\title{
Good Sales Forecasting Information System Using Single Exponential Smoothing Method
}

\author{
Rahmadini Darwas ${ }^{1 *}$, Rahimullaily ${ }^{2}$, Naufal Abdi ${ }^{3}$ \\ ${ }^{123}$ Sistem Informasi, STMIK Indonesia Padang, Indonesia \\ *Corresponding Author: dini@stmikindonesia.ac.id
}

\begin{abstract}
INTISARI
Penelitian ini bertujuan untuk mengetahui perkiraan jumlah barang yang terjual pada salah satu mini market yaitu Toko Tita khususnya Minyak Goreng kemasan 2 Liter untuk periode satu bulan mendatang berdasarkan data penjualan bulan Januari 2016 s/d Desember 2017. Permasalahan yang terjadi pada Toko Tita adalah sulitnya memperkirakan jumlah stok barang dan menghitung estimasi biaya yang dibutuhkan untuk penjualan pada periode satu bulan mendatang. Melalui sistem informasi peramalan yang dibangun dengan metode single exponential smoothing dimana diasumsikan bahwa data berfluktuasi disekitar nilai mean tanpa adanya unsur musiman. Penelitian ini menghasilkan jumlah Minyak Goreng kemasan 2 Liter pada bulan Januari 2018 adalah 42 pcs. Sedangkan estimasi biaya yang dibutuhkan untuk membeli stok Minyak Goreng kemasan 2 Liter pada periode tersebut adalah Rp 609.000,00 dengan harga modal per satuan barang Rp 14.500,00.
\end{abstract}

Kata kunci: Peramalan, Single exponential smoothing, Sistem informasi.

\begin{abstract}
This study aims to determine the estimated number of items sold at one mini-market, namely the Tita shop, especially cooking oil, 2-liter packs for the next month based on sales data for January 2016 to December 2017. The problems that occur at Tita`s shop are is challenging to estimate the amount of stock of goods and calculate the estimated cost required for sales in the next month period. Through a forecasting information system built with the single exponential smoothing method, it is assumed that the data fluctuates around the mean value without any seasonal element. This study resulted in 2 liters of packaged cooking oil in January 2018, which was 42 pcs. Meanwhile, the estimated cost required to buy 2 liters of packaged cooking oil stock in that period is Rp. $609.000,00$ with a capital price unit of goods Rp. $14.500,00$.
\end{abstract}

Keywords: Forecasting, Single exponential smoothing, Information system

\section{INTRODUCTION}

Inventory control in a company is essential in managing the number of goods stored in the warehouse. Predicting the number of items ordered in each period can help management in the decision-making process to determine the number of products that must be produced each month and to prevent excess and shortage of stock in the warehouse. Problems with inventory in the warehouse are widespread and very important because they are related to profit and finance [1]. The number of incoming and outgoing goods must be considered so that there is no excess or shortage of stock in the warehouse. The forecasting method is quantitative inventory control based on historical data (time series) [2]. One of the mini-markets in the city of Padang, Tita`s shop finds it challenging to estimate the amount of stock that must be owned, so Tita's shop cannot calculate the estimated cost needed for sales in that period. Tita's shop also finds it difficult to count the number of items sold in the following one-month period. The same thing also happened in several previous studies, including the Suzuki RJC Ombak company that found it difficult to calculate the available spare parts stock. A system was built using the economic order quantity method to provide spare parts stock information [3]. At the Harapan Mulya Cooperative, Kediri has 
difficulty determining how many types of goods must be added to the stock in the warehouse.

The effort made is to build an administration system application and stock estimation in cooperatives [4]. Furthermore, the cake shop Roemah Snack Mekarsari also has difficulty forecasting cake shop sales. The shop can forecast sales for the next period [5]. However, based on previous research related to predicting these goods, there is no forecasting information system equipped with a sales data management system and goods data to facilitate a store or company estimating stock of goods for the next period. An excellent and computerized data management system can minimize data errors [6]. This forecasting information system uses the single exponential smoothing method. This method is a time series method that uses past data weighting to forecast. The single exponential smoothing method, also known as simple exponential smoothing, is used in short-term forecasting, usually only one month ahead. The model assumes that the data fluctuates around a fixed mean value, with no consistent growth trend or pattern [7]. The single exponential smoothing method is motivated by the absence of consistent growth in the sales data of Cooking oil in 2 Liter Packaging, which can be seen in Figure lantanuari 2016 - Desember 2017

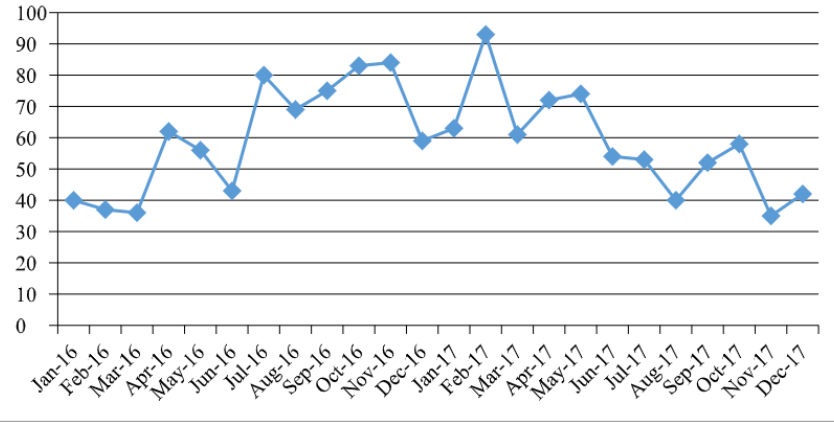

Figure 1. 2 Liter Cooking Oil Sales Chart for January 2016 December 2017

Figure 1 shows historical data on sales of 2 liters of cooking oil which is inconsistent every month. This image also serves as a sample for forecasting other goods at Tita's Store, which has the same data pattern as the data criteria for the single exponential smoothing method.

\section{METHOD}

The data in this study comes from the daily sales data of Toko Tita, which is then added up to become sales data in monthly units. Sales data used in this study is sales data for 2 liters of cooking oil for January 2016 to December 2017, which can be seen in Table 1 .

Table 1. Total Sales Cooking Oil in 2L Packaging Period January 2016 - December 2017

\begin{tabular}{|c|c|c|c|c|c|c|c|c|c|c|c|c|c|c|}
\hline \multirow{2}{*}{ No } & \multirow{2}{*}{ Tahun } & \multicolumn{10}{|c|}{ Bulan } & \multirow{10}{*}{ Jumlah } \\
\hline & & Jan & Feb & Mar & Apr & Mei & Jun & Jul & Ags & Sep & Okt & Nov & Des & \\
\hline 1 & 2016 & 40 & 37 & 36 & 62 & 56 & 43 & 80 & 69 & 75 & 83 & 83 & 59 & 724 \\
\hline 2 & 2017 & 63 & 93 & 61 & 72 & 74 & 54 & 53 & 40 & 52 & 58 & 35 & 42 & 697 \\
\hline \multicolumn{11}{|c|}{ Total } \\
\hline
\end{tabular}

Based on the data in Table 1, the identification process is carried out by calculating the mean value of the data so that the following calculations are obtained:

$$
\bar{X}=\frac{X_{1}+X_{2}+X_{3}+\ldots+X_{n}}{n}=\frac{\sum X}{n}=\frac{1421}{24}=59,20833
$$

Then proceed by entering all sales data into the graph and the mean value obtained. The chart is obtained as shown in Figure 2.

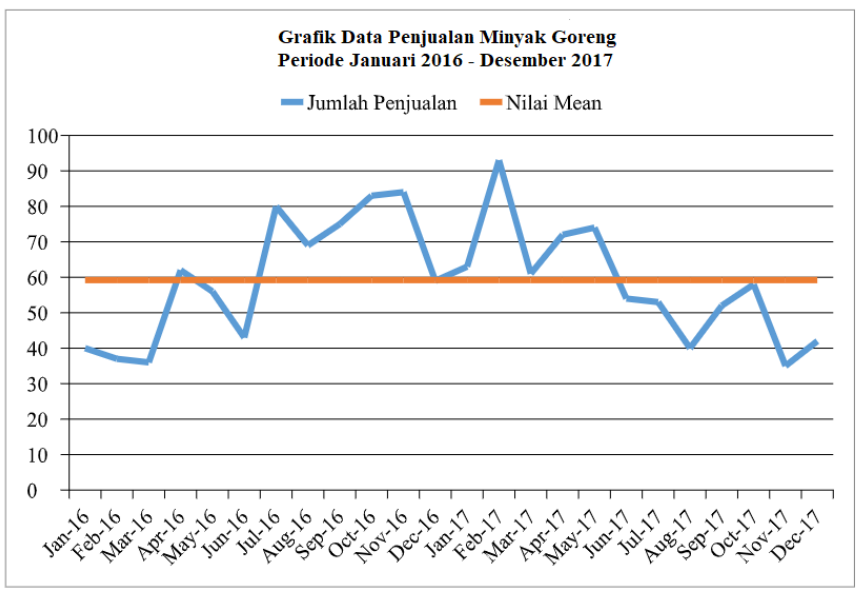

Figure 2. Graph of Sales Data Cooking Oil for January 2016 December 2017

In Figure 2, it can be seen that the sales data pattern for Cooking oil in 2 Liter Packaging for the period January 2016 to December 2017 fluctuated around a fixed mean value, without any trend or seasonal elements. The identification results show a match between this data and the criteria for the pattern of data owned by the Single Exponential Smoothing method so that it can be used in building an information system for forecasting sales of goods in this study.

The method used in forecasting is the single exponential smoothing method. This method is used to predict data in the short term. This method assumes that the data fluctuates around a fixed 
mean value without trends or seasonal elements. Single exponential smoothing emphasizes time series by using smoothing parameters. Parameters range from $0<\alpha<1$. If there is data from $t$ observations, then the forecast value at time $t+1$ [8]

$$
\begin{array}{ll} 
& S_{t+1}=a Y_{t}+(1-a) S_{t}(1) \\
S_{t+1} & =\text { forecast for period } \mathrm{t}+1 \\
Y_{t} & =\text { actual time series value } \\
S_{t} & =\text { forecast on time } \\
\alpha & =\text { parameter value } 0<\alpha<1
\end{array}
$$

The single exponential smoothing method follows data from all periods in forecasting. Each data from observations has involvement in determining the estimated value of the next period. But in the calculation, it is only represented by actual data and forecasting results for the last period because the previous forecast value already contains the previous observation's value.

In applying forecasting methods to available historical data, it is necessary to measure forecasting accuracy [9]. A strategy can be selected based on the size of the smallest error rate [10]. The accuracy of the forecasting results is a measure of the level of difference between the forecasting results and what happened. Some of the commonly used sizes are:

1. Mean Absolute Deviation (MAD)

MAD measures the accuracy of the forecast by averaging the estimated error (the absolute value of each error at the mean absolute deviation, which can be calculated by the formula [11]

$$
M A D=\frac{\sum_{t}^{n}=1\left(T_{t}-Y^{\prime} t\right)}{n}
$$

$$
\begin{array}{ll}
\mathrm{Tt} & =\text { demand data in period } \mathrm{t} \\
\mathrm{Y}^{\prime} \mathrm{t} & =\text { forecast value in period } \mathrm{t} \\
\mathrm{n} & =\text { number of periods }
\end{array}
$$

2. Mean Absolute Percentage Error (MAPE)

MAPE is a measure of relative accuracy based on an absolute value used to determine the percentage deviation of the prediction results from the actual data [12]. By using MAPE in accuracy testing, relatively accurate results are obtained [13]. Forecasting is exact if the MAPE value is $<10 \%$, accurate if the MAPE value is between $10 \%-20 \%$, and inaccurate if the MAPE $>50 \%$ [14]. The formula can calculate MAPE

$$
M A P E=\frac{1}{n} \sum_{t-1}^{n}\left|\frac{e_{t}}{x_{t}}\right| x 100 \%
$$

et $\quad=$ error in period $\mathrm{t}$

$\mathrm{n} \quad=$ number of periods

3. Mean Square Error (MSE)

MSE is the average forecast error squared. MSE is calculated by the formula [15]

$$
\begin{array}{ll}
M S E & =\frac{\sum_{t=1}^{n}\left(X_{t}-F_{t}\right) 2}{n} \\
\mathrm{X}_{\mathrm{t}} & =\text { actual value in period } \mathrm{t} \\
\mathrm{F}_{\mathrm{t}} & =\text { forecasting value in period } \mathrm{t} \\
\mathrm{n} & =\text { number of periods }
\end{array}
$$

The smaller the MSE value, the smaller the prediction error of the forecast.

\section{RESULT AND DISCUSSION}

Based on the analysis carried out, the system built is described in a use case diagram design as shown in Figure 3. Use Case diagram is a scenario description of the interaction that describes the relationship between actors and their activities on the application [16] [17]. Admin can manage account data, item data, data on the number of items sold, forecasting data in which there are 3 sub-menus, namely forecasting history, sales count, and alpha settings. In contrast, the owner can manage data on the number of items sold, forecast data, and print forecasting reports. Employees can only collect item data and control the number of items sold, including importing sales data from sales data recap files in excel format. 


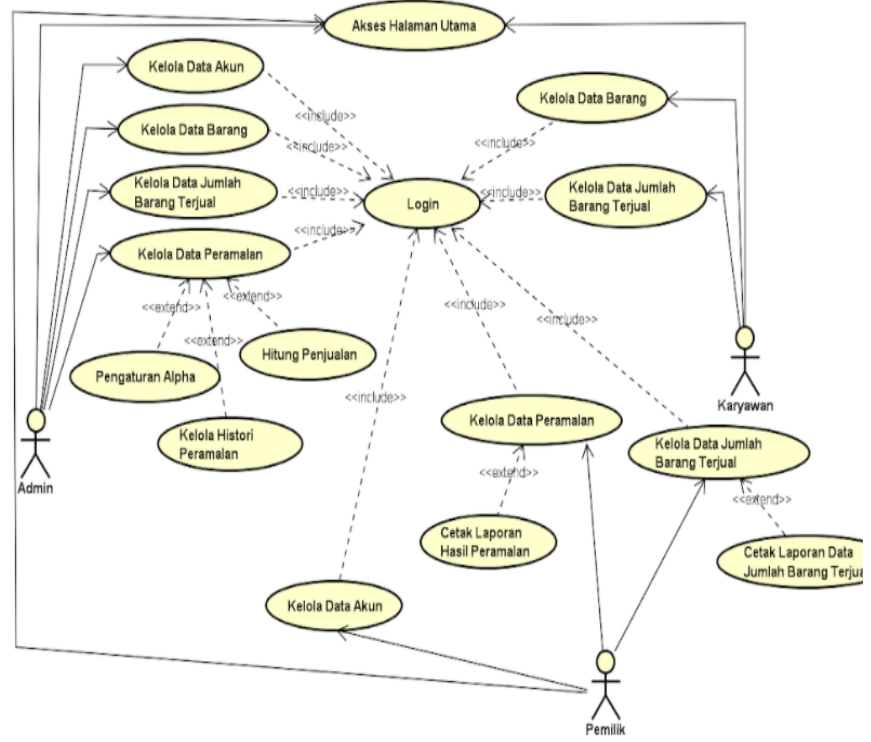

Figure 3. Use Case Diagram Sales Forecasting

The sales count menu contains the sales period to be calculated and sales data from any month that will be used to calculate sales forecasts. The display of the sales count menu can be seen in Figure 4.
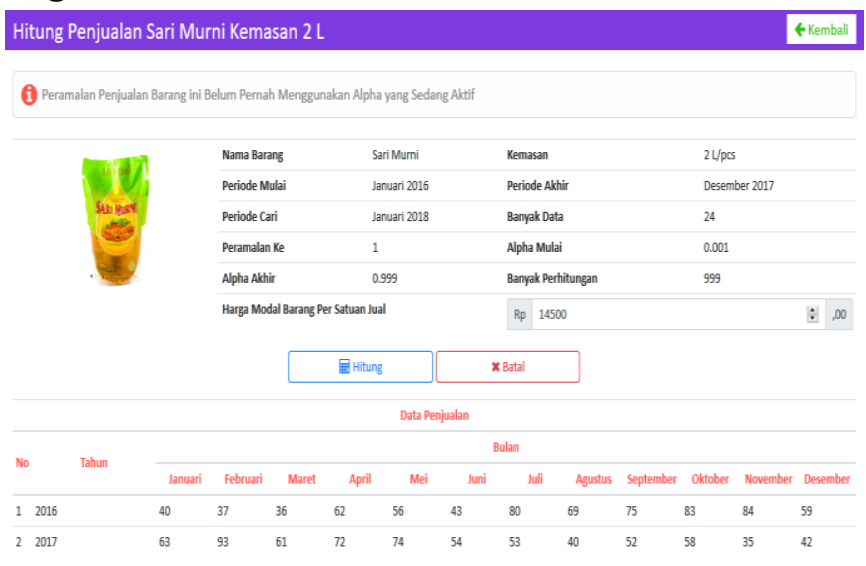

Figure 4. Sales Count Menu

The admin uses the alpha settings menu to set the alpha value that will be used for forecasting. In this menu, adding a new alpha parameter is possible when the existing alpha parameter results in an inaccurate sales forecast. The alpha settings menu can be seen in Figure 5.

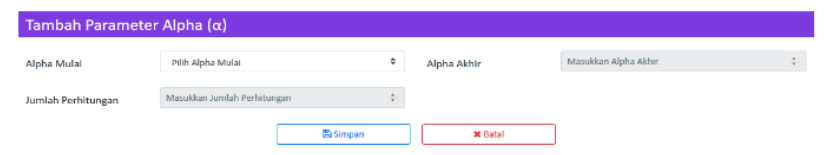

Figure 5. Alpha Settings

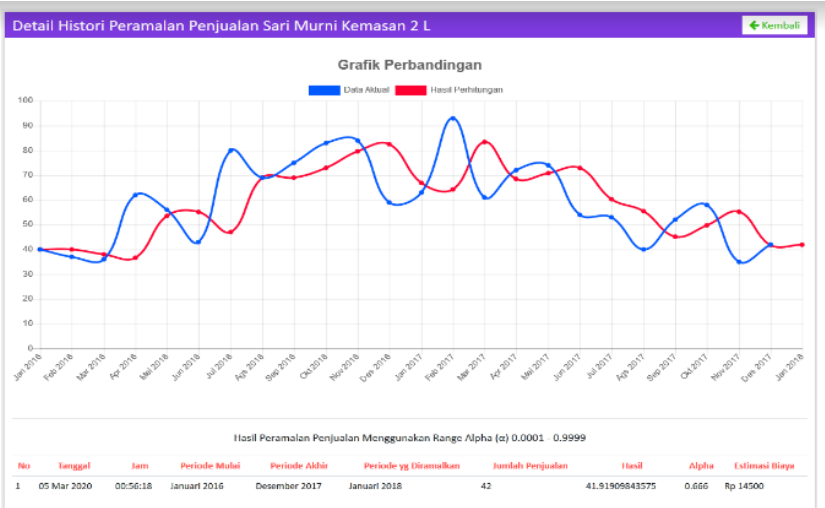

Figure 6. Detailed History of Sales Forecasting Cooking Oil Packaging

Figure 6 shows a comparison chart of data on 2 liters of packaged cooking oil sold with forecasting results, where used is 0.666 , so it can be predicted that sales of 2 liters packaged cooking oil for January 2018 amounted to 42 pcs with an estimated cost of Rp. 14,500.00. To see the accuracy value of the forecasting, it can be seen in the forecasting report shown in Figure 7.

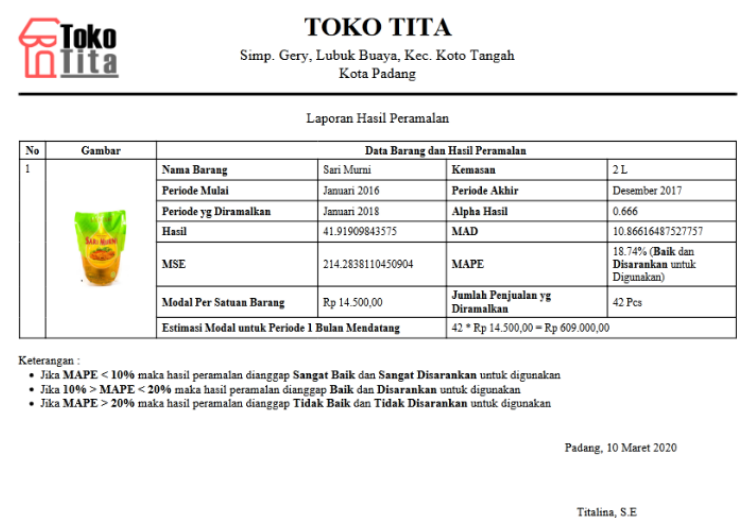

Figure 7. Forecasting Result Report

Figure 7 shows the MAD, MSE, and MAPE values. The MAPE value is $18.74 \%$, which means it is between $10 \%$ - 20\%. This shows the forecasting results are considered reasonable and are recommended to be used.

The single exponential smoothing method in the information system for forecasting sales of goods at Tita Stores can provide an overview of the number of sales that occur in the next 1 month period of an item. Testing the information system for forecasting sales of goods using the Single Exponential Smoothing method can be seen in Table 2. 


\begin{tabular}{|c|c|c|c|c|c|}
\hline $\begin{array}{c}\text { Desc } \\
\text { ripti } \\
\text { on }\end{array}$ & $\begin{array}{c}\text { Preco } \\
\text { nditi } \\
\text { on }\end{array}$ & $\begin{array}{l}\text { Testing } \\
\text { Proced } \\
\text { ure }\end{array}$ & $\begin{array}{c}\text { Expected } \\
\text { Output }\end{array}$ & $\begin{array}{c}\text { Resul } \\
\text { ts }\end{array}$ & $\begin{array}{l}\text { Conclusi } \\
\text { on }\end{array}$ \\
\hline $\begin{array}{l}\text { Login } \\
\text { Input } \\
\text { Test }\end{array}$ & $\begin{array}{l}\text { The } \\
\text { user } \\
\text { has } \\
\text { alread } \\
\text { y } \\
\text { access } \\
\text { ed the } \\
\text { Main } \\
\text { syste } \\
\text { m } \\
\text { page }\end{array}$ & $\begin{array}{l}\text { Access } \\
\text { system } \\
\text { main } \\
\text { page } \\
\text { using } \\
\text { local } \\
\text { URL in } \\
\text { the } \\
\text { browse } \\
\text { r }\end{array}$ & $\begin{array}{l}\text { The } \\
\text { user's } \\
\text { home } \\
\text { page } \\
\text { according } \\
\text { to the } \\
\text { level of } \\
\text { access } \\
\text { they have }\end{array}$ & $\begin{array}{l}\text { The } \\
\text { Input } \\
\text { Login } \\
\text { page } \\
\text { can } \\
\text { be } \\
\text { displa } \\
\text { yed } \\
\text { witho } \\
\text { ut any } \\
\text { error } \\
\text { instru } \\
\text { ctions }\end{array}$ & $\begin{array}{l}\text { The test } \\
\text { is } \\
\text { successfu } \\
\text { l and can } \\
\text { be used } \\
\text { by the } \\
\text { user to } \\
\text { access the } \\
\text { menus on } \\
\text { the } \\
\text { system } \\
\text { according } \\
\text { to the } \\
\text { level of } \\
\text { access } \\
\text { they have }\end{array}$ \\
\hline $\begin{array}{l}\text { Testi } \\
\text { ng } \\
\text { the } \\
\text { Item } \\
\text { Data } \\
\text { menu }\end{array}$ & $\begin{array}{l}\text { The } \\
\text { user } \\
\text { has } \\
\text { succe } \\
\text { ssfull } \\
\text { y } \\
\text { logge } \\
\text { d in } \\
\text { and } \\
\text { has } \\
\text { succe } \\
\text { ssfull } \\
\text { y } \\
\text { access } \\
\text { ed his } \\
\text { Home } \\
\text { page }\end{array}$ & $\begin{array}{l}\text { Click } \\
\text { the } \\
\text { Item } \\
\text { Data } \\
\text { menu }\end{array}$ & $\begin{array}{l}\text { Users can } \\
\text { view, add, } \\
\text { change, } \\
\text { and } \\
\text { delete } \\
\text { item data }\end{array}$ & $\begin{array}{l}\text { The } \\
\text { Item } \\
\text { Data } \\
\text { menu } \\
\text { was } \\
\text { succe } \\
\text { ssfull } \\
\text { y } \\
\text { used } \\
\text { witho } \\
\text { ut any } \\
\text { error } \\
\text { instru } \\
\text { ctions }\end{array}$ & $\begin{array}{l}\text { The test } \\
\text { is } \\
\text { successfu } \\
\text { l and can } \\
\text { be used } \\
\text { by Users } \\
\text { (Admin } \\
\text { and } \\
\text { Employee } \\
\text { s) to } \\
\text { manage } \\
\text { item data. }\end{array}$ \\
\hline $\begin{array}{l}\text { Testi } \\
\text { ng } \\
\text { the } \\
\text { Data } \\
\text { menu } \\
\text { on } \\
\text { the } \\
\text { Amou } \\
\text { nt of } \\
\text { Good } \\
\text { s Sold }\end{array}$ & $\begin{array}{l}\text { The } \\
\text { user } \\
\text { has } \\
\text { succe } \\
\text { ssfull } \\
\text { y } \\
\text { logge } \\
\text { d in } \\
\text { and } \\
\text { succe } \\
\text { ssfull } \\
\text { y } \\
\text { access } \\
\text { ed the } \\
\text { Home } \\
\text { page }\end{array}$ & $\begin{array}{l}\text { Click } \\
\text { the } \\
\text { Data } \\
\text { menu } \\
\text { for the } \\
\text { number } \\
\text { of items } \\
\text { sold }\end{array}$ & $\begin{array}{l}\text { Users can } \\
\text { view, add, } \\
\text { change, } \\
\text { and } \\
\text { delete } \\
\text { data on } \\
\text { the } \\
\text { number } \\
\text { of items } \\
\text { sold }\end{array}$ & $\begin{array}{l}\text { Menu } \\
\text { Data } \\
\text { Numb } \\
\text { er of } \\
\text { Items } \\
\text { Sold } \\
\text { was } \\
\text { succe } \\
\text { ssfull } \\
\text { y } \\
\text { used } \\
\text { witho } \\
\text { ut any } \\
\text { error } \\
\text { instru } \\
\text { ctions }\end{array}$ & $\begin{array}{l}\text { The test } \\
\text { is } \\
\text { successfu } \\
\text { l and can } \\
\text { be used } \\
\text { by Users } \\
\text { (Admin } \\
\text { and } \\
\text { Owner) } \\
\text { to } \\
\text { manage } \\
\text { data on } \\
\text { the } \\
\text { number } \\
\text { of items } \\
\text { sold }\end{array}$ \\
\hline $\begin{array}{l}\text { Forec } \\
\text { astin } \\
\text { g } \\
\text { Histo } \\
\text { ry } \\
\text { menu } \\
\text { testin } \\
\text { g }\end{array}$ & $\begin{array}{l}\text { The } \\
\text { user } \\
\text { has } \\
\text { succe } \\
\text { ssfull } \\
\text { y } \\
\text { logge } \\
\text { d in } \\
\text { and } \\
\text { succe } \\
\text { ssfull }\end{array}$ & $\begin{array}{l}\text { Click } \\
\text { the } \\
\text { Forecas } \\
\text { ting } \\
\text { History } \\
\text { menu }\end{array}$ & $\begin{array}{l}\text { Users can } \\
\text { view } \\
\text { details } \\
\text { and } \\
\text { delete all } \\
\text { sales } \\
\text { forecasts } \\
\text { ever done }\end{array}$ & $\begin{array}{l}\text { Forec } \\
\text { asting } \\
\text { histor } \\
\mathrm{y} \text { is } \\
\text { succe } \\
\text { ssfull } \\
\text { y } \\
\text { displa } \\
\text { yed } \\
\text { witho } \\
\text { ut any }\end{array}$ & $\begin{array}{l}\text { The test } \\
\text { is } \\
\text { successfu } \\
\text { l and can } \\
\text { be used } \\
\text { by Users } \\
\text { (Admin } \\
\text { and } \\
\text { Owner) } \\
\text { to } \\
\text { manage }\end{array}$ \\
\hline
\end{tabular}

\begin{tabular}{|c|c|c|c|c|c|}
\hline $\begin{array}{c}\text { Desc } \\
\text { ripti } \\
\text { on }\end{array}$ & $\begin{array}{c}\text { Preco } \\
\text { nditi } \\
\text { on } \\
\end{array}$ & $\begin{array}{c}\text { Testing } \\
\text { Proced } \\
\text { ure } \\
\end{array}$ & $\begin{array}{c}\text { Expected } \\
\text { Output }\end{array}$ & $\begin{array}{c}\text { Resul } \\
\text { ts }\end{array}$ & $\begin{array}{c}\text { Conclusi } \\
\text { on }\end{array}$ \\
\hline & $\begin{array}{l}\mathrm{y} \\
\text { access } \\
\text { ed the } \\
\text { Home } \\
\text { page }\end{array}$ & & & $\begin{array}{l}\text { error } \\
\text { instru } \\
\text { ctions }\end{array}$ & $\begin{array}{l}\text { all } \\
\text { forecastin } \\
\text { g data. }\end{array}$ \\
\hline $\begin{array}{l}\text { Testi } \\
\text { ng } \\
\text { the } \\
\text { Count } \\
\text { Sales } \\
\text { menu }\end{array}$ & $\begin{array}{l}\text { The } \\
\text { user } \\
\text { has } \\
\text { succe } \\
\text { ssfull } \\
\text { y } \\
\text { logge } \\
\text { d in } \\
\text { and } \\
\text { has } \\
\text { succe } \\
\text { ssfull } \\
\text { y } \\
\text { access } \\
\text { ed his } \\
\text { Home } \\
\text { page }\end{array}$ & $\begin{array}{l}\text { Click } \\
\text { the } \\
\text { Count } \\
\text { Sales } \\
\text { menu }\end{array}$ & $\begin{array}{l}\text { Users can } \\
\text { calculate } \\
\text { sales that } \\
\text { will occur } \\
\text { in the } \\
\text { next } 1 \\
\text { month } \\
\text { period of } \\
\text { an item }\end{array}$ & $\begin{array}{l}\text { The } \\
\text { calcul } \\
\text { ation } \\
\text { of the } \\
\text { numb } \\
\text { er of } \\
\text { items } \\
\text { sold } \\
\text { in the } \\
\text { next } 1 \\
\text { mont } \\
\text { h } \\
\text { perio } \\
\text { d was } \\
\text { succe } \\
\text { ssfull } \\
\text { y } \\
\text { used } \\
\text { witho } \\
\text { ut any } \\
\text { error } \\
\text { instru } \\
\text { ctions }\end{array}$ & $\begin{array}{l}\text { The test } \\
\text { is } \\
\text { successfu } \\
\text { l and can } \\
\text { be used } \\
\text { by the } \\
\text { User } \\
\text { (Admin) } \\
\text { to } \\
\text { forecast } \\
\text { the } \\
\text { number } \\
\text { of sales in } \\
\text { the next } 1 \\
\text { month } \\
\text { period of } \\
\text { an item. }\end{array}$ \\
\hline $\begin{array}{l}\text { Alpha } \\
\text { Settin } \\
\text { gs } \\
\text { menu } \\
\text { testin } \\
\text { g }\end{array}$ & $\begin{array}{l}\text { The } \\
\text { user } \\
\text { has } \\
\text { succe } \\
\text { ssfull } \\
\text { y } \\
\text { logge } \\
\text { d in } \\
\text { and } \\
\text { has } \\
\text { succe } \\
\text { ssfull } \\
\text { y } \\
\text { access } \\
\text { ed his } \\
\text { Home } \\
\text { page }\end{array}$ & $\begin{array}{l}\text { Click } \\
\text { the } \\
\text { Alpha } \\
\text { Settings } \\
\text { menu }\end{array}$ & $\begin{array}{l}\text { Users can } \\
\text { view, } \\
\text { modify } \\
\text { alpha } \\
\text { data, } \\
\text { delete, } \\
\text { and } \\
\text { change } \\
\text { the active } \\
\text { alpha } \\
\text { paramete } \\
\text { r }\end{array}$ & $\begin{array}{l}\text { The } \\
\text { Alpha } \\
\text { Setup } \\
\text { Menu } \\
\text { was } \\
\text { succe } \\
\text { ssfull } \\
\text { y } \\
\text { used } \\
\text { witho } \\
\text { ut any } \\
\text { error } \\
\text { instru } \\
\text { ctions }\end{array}$ & $\begin{array}{l}\text { The test } \\
\text { is } \\
\text { successfu } \\
\text { l and can } \\
\text { be used } \\
\text { by the } \\
\text { user } \\
\text { (Admin) } \\
\text { to } \\
\text { manage } \\
\text { all alpha } \\
\text { paramete } \\
\text { r data } \\
\text { whether } \\
\text { or not to } \\
\text { be used } \\
\text { in the } \\
\text { sales } \\
\text { forecastin } \\
\text { g process. }\end{array}$ \\
\hline
\end{tabular}

Based on Table 2, it can be concluded that all functions in the system were successfully executed without any errors and proved that the system could be implemented for forecasting sales of goods at Tita's Store for the next 1 month period.

\section{CONCLUSION}

With this system, Tita's Store can find out the number of items sold in the next 1 month period so 
that the risk of loss due to errors in determining the number of things that must be in stock can be reduced, and the use of business capital is more targeted. Tita Stores can determine the estimated cost needed for sales in the next 1 month period based on the capital price of goods per unit of purchase entered before the sales forecasting process when the sales forecast is completed. This system can be used for all types of goods that have the same data pattern with the data criteria of the single exponential smoothing method.

\section{REFERENCES}

[1] Pritalia, "Penerapan Algoritma C4 . 5 untuk Penentuan Ketersediaan Barang E-commerce," Indones. J. Inf. Syst., vol. 1, no. 1, pp. 47-56, 2018.

[2] Y. Ariyanto et al., "Sistem Informasi Peramalan Penjualan Barang Dengan Metode Double Exponential Smoothing Pada Istana Sayur," J. Inform. Polinema, vol. 6, no. 3, pp. 9-14, 2020.

[3] Elisawati and M. Herri, "Sistem Inventory Suku Cadang Sepeda Motor Untuk ( Studi Kasus : Pt . SuZUki RJC Ombak )," J. Inform. Manaj. dan Komput., vol. 8, no. 2, pp. 1-7, 2016.

[4] R. Firliana and E. K. Dewi, "Sistem Informasi Administrasi dan Peramalan Stok Barang," in SNATIKA, Seminar Nasional Teknologi Informasi, Komunikasi dan Aplikasinya, 2017, pp. 56-61.

[5] M. W. Astuti, A. Sofro, and A. Oktaviarina, "Peramalan Penjualan Kue Pada Toko Roemah Snack Mekarsari Dengan Metode Single Exponential Smoothing," J. Ilm. Mat., vol. 6, no. 2, pp. 70-74, 2018.

[6] R. Darwas, G. Yanto, and M. Putri, "Sistem Informasi Pengolahan Data Asrama Mahasiswa Universitas Andalas," J. Teknol. Inf. dan Pendidik., vol. 11, no. 2, 2018.

[6] D. M. Efendi and F. Ardhy, "Penerapan Data Mining Untuk Peramalan Penjualan Obat dengan Menggunakan Single Exponential Smoothing di Apotek Hamzah Farma," in Seminar Nasional Teknologi dan Bisnis, 2018, pp. 198-203.

[7] M. Kramer, "Best Practices in Systems Development Lifecycle: An Analyses Based on the Waterfall Model," Rev. Bus. Finance. Stud., vol. 9, no. 1, pp. 77-84, 2019.

[8] M. N. Arridho and Y. Astuti, "Penerapan Metode Single Exponential Smoothing untuk Memprediksi Penjualan Katering pada Kedai Pojok Kedaung," J. Ilm. Intech Inf. Technol. J. UMUS, vol. 2, no. 02, pp. 35-44, 2020.
[9] G. Putra and A. R. Maulud, "Peramalan Kebutuhan Batubara Menggunakan Metode Single Exponential Smoothing di PT . Solusi Bangun Andalas," J. Optim., vol. 6, no. 2, pp. 131-141, 2020.

[10] A. Khadijah, E. Krisnaningsih, E. S. Apriani, and F. S. Handika, "Usulan Penerapan Metode Peramalan Dalam Menentukan Tingkat Penjualan Produk Abc Di PT Solusi Arta Jaya," in Prosiding Industrial Engineering Conference (IEC) 2020, 2020, pp. 298-309.

[11] U. Khair, H. Fahmi, S. Al Hakim, and R. Rahim, "Forecasting Error Calculation with Mean Absolute Deviation and Mean Absolute Percentage Error Forecasting Error Calculation with Mean Absolute Deviation and Mean Absolute Percentage Error," in Journal of Physics : Conference Series, 2017.

[12] R. D. Laksmana, E. Santoso, and B. Rahayudi, "Prediksi Penjualan Roti Menggunakan Metode Exponential Smoothing ( Studi Kasus : Harum Bakery )," J. Pengemb. Teknol. Inf. dan Ilmu Komput., vol. 3, no. 5, pp. 4933-4941, 2019.

[13] N. A. Nugroho and A. Purqon, "Analisis 9 Saham Sektor Industri di Indonesia Menggunakan Metode SVR," in Prosiding SKF 2015, 2015, pp. 295-300.

[14] M. Moreno et al., "Using the R-MAPE index as a resistant measure of forecast accuracy," Psicothema, vol. 25, no. 4, pp. 500-506, 2013.

[15] W. Handoko, "prediksi jumlah penerimaan mahasiswa baru dengan metode single exponential smoothing ( studi kasus: amik royal kisaran )" Jurteksi (Jurnal Teknol. danSistem Inf., vol. V, no. 2, pp. 125-132, 2019..

[16]T. Dirwanto, A. Huda, and A. Hadi, "Sistem Informasi Pengelolaan Hotel Di Kota Padang Menggunakan Mapbox Graphic Library Berbasis Framework Codeigniter," J. Teknol. Inf. Pendidik., vol. 11, no. 1, pp. 94-107, 2018.

[17]Thamrin, D. Faiza, A. Hadi, K. Budayawan, G. Farell, and I. Novid, "Designing The Information System For Data Collection Of Covid-19 Symptoms For Indonesian Citizens," J. Teknol. dan Sist. Inf., vol. 14, no. 1, 2021.

[18] A. D. Samala, B. R. Fajri, and F. Ranuarja, "Pemrograman $\mathrm{C}++$, The Beginning: from Zero to One." UNP PRESS, 2021. 